Prof. Dr. Ricardo Baroudi

Editor-in-Chief

\section{Revista Brasileira de Cirurgia Plástica (Brazilian Journal of Plastic Surgery)}

Dear Editor

With reference to the letter by Dr. Gal Moreira Dini, I would like make the following comments.

The article entitled "Augmentation brachioplasty" by Dini and Ferreira ${ }^{1}$, should be listed in our references, as indexed in the main databases. This article, published under section "Letters and Viewpoints," was not found during our initial search. Because of its relevance and to render it easily available, we recommend its publication as an original article.

This study proposes a new technical method that involves a different approach, considering that the implant used differs from those used in previous studies. Our premise is that an ideal implant should provide volume to the region in which is located, an effect achieved by using solid silicone (elastomer). Moreover, it should also define the contour, which can be ensured by placing silicone gel on the surface. This would allow the creation of a mixed implant, which is not yet available commercially.

Silimed $^{\circledR}$ has requested that patents not be held on its products.
In our opinion, this technical method is particularly relevant. It could stimulate the interest of surgeons for this subject area and the generation of new products by this company, which would only occur if the demand for this implant increases. Moreover, we are always open to suggestions and criticism.

The development of new techniques and their constant improvement is essential for Brazil to maintain its position as the leading country in Plastic Surgery.

Sincerely,

Ivan Abadesso

Plastic surgeon, full member of the Sociedade Brasileira de Cirurgia Plástica (Brazilian Society of Plastic Surgery), Rio de Janeiro, RJ, Brazil

Fernando Serra Plastic surgeon, full member of the Sociedade Brasileira de Cirurgia Plástica (Brazilian Society of Plastic Surgery), Rio de Janeiro, RJ, Brazil

\section{REFERENCE}

1. Dini GM, Ferreira LM. Augmentation brachioplasty. Plast Reconstr Surg. 2006;117(6):2109-11.

Correspondence received: June 26, 2012

Correspondence accepted: June 26, 2012
Correspondence to:

Ivan Abadesso

Av. das Américas, 500 - Bloco 20 - Sala 202 - Barra da Tijuca - Rio de Janeiro, RJ, Brazil - CEP 22640-100

E-mail: abadesso.ivan@gmail.com 